\title{
わが国のがん疼痛治療薬における問題点とその解決方法
}

\author{
国分秀也, ${ }^{*}, a$ 的場元弘, ${ }^{b}$ 山田安彦, ${ }^{c}$ 矢後和夫 ${ }^{a}$
}

\section{Solutions for the Clinical Problems of Analgesics for Cancer Pain Treatment in Japan}

\author{
Hideya KoKubun, ${ }^{*, a}$ Motohiro MAtoba, ${ }^{b}$ Yasuhiko YAmada, ${ }^{c}$ and Kazuo YAGO ${ }^{a}$ \\ ${ }^{a}$ Department of Pharmacy, Kitasato University Hospital, 1-15-1 Kitasato, Minami-ku, Sagamihara, Kanagawa \\ 252-0375, Japan, ${ }^{b}$ Department of Palliative Medicine and Psycho-Oncology, National Cancer Center, \\ 5-1-1 Tsukiji, Chuo-ku, Tokyo 104-0045, Japan, and 'Department of Clinical Evaluation of \\ Drug Efficacy, School of Pharmacy, Tokyo University of Phamacy and Life Science, \\ 1432-1 Horinouchi, Hachioji, Tokyo 192-0392, Japan
}

(Received April 5, 2010; Accepted October 15, 2010; Published online October 26, 2010)

\begin{abstract}
The pain experienced by cancer patients can be managed in 70-90\% of cases by the World Health Organisation protocol for cancer pain. However, cancer pain treatment in Japan is not sufficiently effective. To use medicine safely and effectively, various problems must be solved. Therefore, in this study, appropriate usage of cancer pain treatment was examined. We were able to use acetaminophen suppositories $(800 \mathrm{mg}$ each) in cancer pain patients. It was suggested that high serum concentrations of oxycodone and hydrocotarnine might be observed in geriatric patients or in the state of decreased hepatic blood flow, making dose adjustment is necessary for such patients. We also clarified that the conversion ratio from oral oxycodone to intravenous ocycodone/hydrocotarnine was $0.71 \pm 0.12$. In addition, we clarified the pharmacokinetics of controlled-release oxycodone in patients with cancer pain. Moreover, the findings of our study indicate that in the steady state, the serum concentrations of fentanyl are not maintained at a constant level for 3 days following the use of transdermal fentanyl. We established a method of appropriately passing a nasal duct for sustained release of fine granules of morphine sulfate. Resolution of the clinical problems associated with cancer pain treatments is anticipated to allow the proper use of cancer pain treatments in Japan.
\end{abstract}

Key words — cancer pain; appropriate usage; fentanyl; morphine; oxcodone; acetaminophen

\section{1. はじめに}

末期がん患者は，疼痛を始め，様々な身体症状や 精神的苦痛に悩まされながら死を迎える場合が多 く，緩和ケアではこれらの症状をコントロールし， 患者あるいはその家族に対して実現し得る最高の QOL（Quality of life）を提供することを目標にし ている. がん患者における疼痛の出現頻度は, がん の原発部位や病期, 病態, 転移などにより異なる が，がんの進行に伴って高くなる. ${ }^{1)}$ 末期がん患者 においては，75\%の患者で疼痛の訴えがあり, ${ }^{2-5)}$ がん疼痛はがん患者にとって, 非常に重要な問題と なっている。世界保健機関（WHO; World Health

${ }^{a}$ 北里大学病院薬剂部（干252-0375 神奈川県相模原市 南区北里 1-15-1), b独立行政法人国立がん研究セン 夕一中央病院緩和医療科・精神腫瘍科（广104-0045 東 京都中央区築地 5-1-1), $c$ 東京薬科大学薬学部臨床薬効 解析学教室（广192-0392 東京都八王子市堀之内 14321)

*e-mail: kokubun@kitasato-u.ac.jp
Organization）では，すべてのがん患者を疼痛から 解放することを目的に 1982 年より WHO がん疼痛 救済プログラムを開始し，1986 年には WHO 方式 がん疼痛治療法を示した「Cancer Pain Relief 」6) 発刊した。この治療法により 70-90\%の除痛率が得 られることが示され, 6) その妥当性や有効性を評価 する報告がなされている. ${ }^{7-9)}$

WHO 方式がん疼痛治療法で推奨されている鎮痛 薬のうち，わが国でがん疼痛患者に使用可能な薬剤 の種類は近年まで限られており，2001 年までには 強オピオイド鎮痛薬として，モルヒネ(徐放錠, 坐 剂，注射剂）、オキシコドン（複方注射剂）及びブ プレノルフィン（坐剤，注射剤）が上市されている に過ぎなかった。ささに，オキシコドン注射剤は単 独成分の製剂はなく，ヒドロコタルニンとの合剤の みであること，ブプレノルフィンは天井効果（有効 限界）があり $6,10,11)$ 投与量に限界があること等, 臨 床では使用し難い薬剤であったため, わが国では 
2001 年までモルヒネ製剤を中心としたがん疼痛治 療が行われてきた。その後，2001 年 9 月に硫酸モ ルヒネ徐放細粒，2002 年 3 月にフェンタニルパッ チ， 2003 年 7 月にはオキシコドン徐放錠が上市さ れ，がん疼痛治療薬の選択肢が増加した。しかし， これら新規オピオイド製剤には，臨床において適正 に使用する上での十分なデータが整備されておら ず，薬剤を安全かつ効果的に使用するためには，種 々の問題点を解決する必要があった。また，WHO 方式がん疼痛治療法で推奨されている鎮痛薬のう ち，わが国で上市されている薬剤であっても，がん 疼痛に対しての適切な用法・用量が設定されていな いなど，臨床使用する上での問題点があった（Table 1).

本研究では, 質の高いがん疼痛治療を推進するた め, これらの問題点を解決すべく，がん疼痛治療薬 の適正使用における検討を行った。

2. 高用量アセトアミノフェン坐剤の臨床適用の 検討 ${ }^{12)}$

アニリン系解熱鎮痛薬であるアセトアミノフェン （APAP; $N$-acetyl-p-aminophenol）は，他の非ステ ロイド鎮痛薬（NSAIDs; nonsteroidal anti-inflammatory drugs）よりも比較的安全性の高い薬物とし て広く認知されており, ${ }^{13-15)}$ WHO 方式がん疼痛治 療法の中では第 1 段階の基本非オピオイド鎮痛薬と して推奨されている．中等度から重度の疼痛に対し ては，1 回 $1000 \mathrm{mg} ， 1$ 日量上限 $4000 \mathrm{mg}$ が至適用 量であることが確認されており, ${ }^{16,17)} \mathrm{WHO}$ 方式が
ん疼痛治療法においても 1 回 650-1000 mg, 1 日量 として $6000 \mathrm{mg}$ を超えないこととされている。ま た，欧米諸国や韓国においても 1 回 500-1000 mg, 1 日量上限 $4000 \mathrm{mg}$ の用量で用いられている。しか し，わが国における APAP の用法用量は，解熱あ るいは軽度の疼痛に対して設定されたものであるた め 1 回 300-500 mg，1 日 900-1500 mg であり，こ の用量ではがん疼痛患者に用いる場合，十分な鎮痛 効果が期待できない，そのため，わが国においても がん疼痛患者に用いる場合，海外における用法用量 （1 回 500-1000 mg，1 日量上限 $4000 \mathrm{mg}$ ）を目安に 投与されているのが現状である。しかし，市販され ている APAP 製剤は，散剤，液剂，錠剤及び坐剤 のみで注射剂は存在しない。そのため，経口摂取不 可能ながん疼痛患者に APAP を投与する際は，坐 剂を使用しなければならないが，市販されている APAP 坐剂の添付文書上の適応は「小児領域にお ける解熱・鎮痛」のみで，製剤規格は 1 個 $200 \mathrm{mg}$ が最大量であり，がん疼痛患者に用いる場合，1回 に 3-5 個挿入する必要があり坐剂の使用方法として は適切とは言えない。そこで, 1 個 $600 \mathrm{mg}$ 及び 800 $\mathrm{mg}$ の高用量 APAP 坐剂を院内特殊製剂として調製 し，がん疼痛患者に対して臨床使用可能であるかを 検討した。

対象患者は，APAP 末（ピリナジン®）を経口 投与した 4 例（前立腺がん 2 例，膀胱がん 1 例，腎 がん 1 例）及び高用量 APAP 坐剂を直腸内投与し た 5 例（前立腺がん 2 例，下咽頭がん 1 例，食道が

Table 1. Problems on Clinical Use of Cancer Pain Drugs in Japan and Our Considerations

\begin{tabular}{|c|c|c|}
\hline 鎮 痛 薬 & 問 題 点 & 検 討 内容 \\
\hline アセトアミノフェン坐剤 & $\begin{array}{l}\text { ・市販製剂の最大規格が } 200 \text { mg であり，がん疼痛治 } \\
\text { 療に用いるには低用量 }\end{array}$ & ・高用量坐剂の調製及び臨床評価の \\
\hline \multirow[t]{2}{*}{ 複方オキシコドン注射剤 } & $\begin{array}{l}\text { ・がん疼痛患者を対象とした血中薬物動態に関する情 } \\
\text { 報が不十分 }\end{array}$ & ・がん疼痛患者の血中薬物動態の検討 \\
\hline & ・オキシコドン徐放錠との用量変換比が未確立 & ・オキシコドン徐放錠との用量変換比の検討 \\
\hline オキシコドン徐放錠 & $\begin{array}{l}\text { ・臨床における即効性を期待した不適切な頓服使用 } \\
\text { ・貲便中から排出された ghost pill 中のオキシコドン } \\
\text { 残存量が不明 }\end{array}$ & $\begin{array}{l}\text { ・吸収動態の検討 } \\
\text { ・ghost pill 中のオキシコドン定量 }\end{array}$ \\
\hline \multirow[t]{2}{*}{ フェンタニルパッチ } & $\begin{array}{l}\text { ・通常の用法（3 日に } 1 \text { 回貼付）における貼付後 } 3 \text { 日 } \\
\text { 目の疼痛出現 }\end{array}$ & •一貼付期間内の血中濃度推移の検討 \\
\hline & • 初回投与時や増量時に呼吸抑制等の副作用発現 & ・投与量調節法（半面貼付法）の検討 \\
\hline 硫酸モルヒネ徐放細粒 & ・経鼻管投与によるカテーテルの閉塞 & •適正な経鼻管投与方法の検討 \\
\hline
\end{tabular}


ん 1 例，大腸がん 1 例）とした。 APAP の投与方 法は，経口及び直腸内投与とも 1 回 600-800 mg，1 日 4 回，6 時間毎の繰り返し投与とした。高用量 APAP 坐剤の調製は，まず乳剤性基剤であるウィ テプゾール H-15（30 g) をビーカーにとり，水浴 上で加温溶融した。次に, APAP 末 $(800 \mathrm{mg}$ 坐剂 の場合；16 g, $600 \mathrm{mg}$ 坐剂の場合；12 g）を乳鉢中 にとり研和微細末とし，これにあらかじめ加温溶融 したウィテプゾール H-15 を少量加えペースト状に し，ビーカーに戻した。再び少量のウィテプゾール $\mathrm{H}-15$ を乳鉢に加え，内容物を洗い込み，ビーカー に戻した（これを数回繰り返した）。全質均等にし た後，擋汼しながら冷却し，ある程度粘度が高まっ た状態で $2.25 \mathrm{ml}$ 坐剂コンテナ 20 個に充填し, 固 化するまで放置した。血清中 APAP 濃度測定は, 蛍光偏光免疫測定法 (FPIA; fluorescence polarization immunoassay）を用いた TDX アナライザー （アボットジャパンK.K.）にて行い，採血は 6 時間 毎に 4 回以上APAP を投与した定常状態における APAP 投与直前の 1 ポイントとした。さらに APAP の内服剤及び坐剂における効果，副作用を 確認した.

その結果, 高用量 APAP 坐剂は, 市販品のジク ロフェナクナトリウム坐剤（ボルタレン坐剤 50 mg）とほぼ同じ大きさであり，臨床使用可能な大
きさに調製することができた。また，APAP 内服 剂あるいは高用量 APAP 坐剂を使用した患者にお いて，6 時間毎に 4 回以上投与した定常状態におけ る投与直前の血清中 APAP 濃度の平均值はぞれぞ れ $8.4 \pm 5.4 \mathrm{mg} / 1$ 及び $8.6 \pm 4.5 \mathrm{mg} / 1$ であった。ま た，投与直前の血清中 APAP 濃度を 1 日投与量で 除した值の平均はそれぞれ $2.78 \pm 1.66 \mathrm{mg} / \mathrm{l} / \mathrm{g}$ 及び $2.99 \pm 1.88 \mathrm{mg} / \mathrm{l} / \mathrm{g}$ であり (Table 2)，ほぼ同等な 值を示し有意差はなかった $(p=0.545)$.

APAP 市販坐剂 $400 \mathrm{mg}$ を単回直腸内投与した時 の薬物動態18) は, 最高血清中濃度; $4.2 \pm 0.3 \mathrm{mg}$ / 1 , 最高血清中濃度到達時間 ; $1.6 \pm 0.2$ 時間，消失 半減期 $; 2.7 \pm 0.3$ 時間と報告されている。 また,

APAP 内服剂 $1000 \mathrm{mg}$ を単回経口投与した時の薬 物動態 ${ }^{19)}$ は，最高血清中濃度 ; $9.0 \pm 0.4 \mathrm{mg} / 1$, 最 高血清中濃度到達時間； $0.9 \pm 0.1$ 時間，消失半減 期 $; 2.4 \pm 0.1$ 時間と報告されている。吸収に関して は，経口投与でほぼ完全に吸収され，そのバイオア ベイラビリティは，1000 mg 単回投与の場合 $89 \%$ と報告されている. ${ }^{20)}$ 今回の結果では，6 時間毎に 1 日 4 回，1 回 600-800 mg の用法・用量におい て，高用量 APAP 坐剂あるいは APAP 内服剂を使 用した患者の投与直前における血清中 APAP 濃度 は， $8.6 \pm 4.5 \mathrm{mg} / 1$ 及び $8.4 \pm 5.4 \mathrm{mg} / 1$ とほぼ同等で あった．Walter-Sack ら 21$) の$ 報告においても，健常

Table 2. The Steady-state Serum through Acetaminophen Concentration after More than Four Times Administration of Acetaminophen and Liver Function Parameters before and after Administration of Acetaminophen

\begin{tabular}{|c|c|c|c|c|c|c|c|c|c|}
\hline & \multirow{2}{*}{$\begin{array}{l}\text { Patient } \\
\text { No. }\end{array}$} & \multirow{2}{*}{$\begin{array}{c}\text { Serum } \\
\text { concentration } \\
(\mathrm{mg} / \mathrm{l})\end{array}$} & \multirow{2}{*}{$\begin{array}{c}\text { Serum } \\
\text { concentration } \\
\text { /dose }(\mathrm{mg} / \mathrm{l} / \mathrm{g})\end{array}$} & \multicolumn{3}{|c|}{ Before administration } & \multicolumn{3}{|c|}{ After 1 week of administration } \\
\hline & & & & $\begin{array}{l}\text { AST } \\
(\mathrm{IU} / \mathrm{l})\end{array}$ & $\begin{array}{l}\mathrm{ALT} \\
(\mathrm{IU} / \mathrm{l})\end{array}$ & $\begin{array}{c}\text { T-BiL } \\
(\mathrm{mg} / \mathrm{dl})\end{array}$ & $\begin{array}{c}\text { AST } \\
(\mathrm{IU} / 1)\end{array}$ & $\begin{array}{c}\text { ALT } \\
(\mathrm{IU} / \mathrm{l})\end{array}$ & $\begin{array}{c}\text { T-BiL } \\
(\mathrm{mg} / \mathrm{dl})\end{array}$ \\
\hline \multirow{6}{*}{ Oral } & 1 & 3.1 & 0.97 & - & - & - & - & - & - \\
\hline & 2 & 6.3 & 2.25 & 14 & 4 & 0.4 & 14 & 6 & 0.3 \\
\hline & 3 & 8.3 & 2.96 & 14 & 18 & 0.2 & 34 & 10 & 0.4 \\
\hline & $4-1$ & 15.8 & 4.94 & 20 & 14 & 0.5 & 25 & 19 & 0.2 \\
\hline & Mean & 8.4 & 2.78 & 16.0 & 12.0 & 0.37 & 24.3 & 11.7 & 0.30 \\
\hline & S.D. & 5.4 & 1.66 & 3.5 & 7.2 & 0.15 & 10.0 & 6.7 & 0.10 \\
\hline \multirow{7}{*}{ Rectal } & $4-2$ & 13.0 & 4.06 & 110 & 15 & 0.2 & 167 & 7 & - \\
\hline & 5 & 5.2 & 1.63 & 13 & 14 & 0.2 & 14 & 18 & 0.2 \\
\hline & 6 & 13.8 & 5.75 & 40 & 34 & 1 & 22 & 17 & 0.6 \\
\hline & 7 & 4.2 & 1.31 & 24 & 26 & 0.4 & - & - & - \\
\hline & 8 & 7.0 & 2.19 & 26 & 21 & 0.2 & 43 & 33 & 0.2 \\
\hline & Mean & 8.6 & 2.99 & 42.6 & 22.0 & 0.40 & 64.1 & 18.8 & 0.33 \\
\hline & S.D. & 4.5 & 1.88 & 38.9 & 8.3 & 0.35 & 70.9 & 10.7 & 0.23 \\
\hline
\end{tabular}


成人 12 例を対象として，同用量による APAP 経口 投与と直腸内投与で $\mathrm{AUC}_{0-12 \mathrm{~h}}$ に有意差がないこと を確認しており，本結果と同様であった。また， Marel ら ${ }^{22)}$ は術後小児 40 例を対象とした試験にお いて，APAP 経口投与と直腸内投与を比較して, 鎮痛効果及び血清中 APAP 濃度が同等であること を示している。これらのことから，院内特殊製剤と して調製した高用量 APAP 坐剂は，良好に吸収さ れていると考えられ，APAP 内服剤との用量変換 比は $1: 1$ でよいと考えられた。また，副作用に関 して (Table 2), 高用量 APAP 坐剂及び内服剂と もに投与前と投与 1 週間後で肝機能検查值（AST， ALT 及び総ビリルビン值）に有意な変動はなく異 常值は確認されなかった（ $p=0.173,0.735$ 及び 0.273)。ささらに，APAP を経口投与から直腸内投与 に切り替えた 1 症例（症例 4）では，切り替え前後 で鎮痛効果に変化はなく, APAP 内服剂と高用量 APAP 坐剂の血清中 APAP 濃度は，それぞれ 15.8 $\mathrm{mg} / 1$ 及び $13.0 \mathrm{mg} / 1$ であり高用量 APAP 坐剂の方 が若干低值であったが，ほぼ同等な值を示してい た。しかし，症例 4 は心不全の既往を有し，APAP との因果関係は不明であるが，APAP 投与開始 3 カ月後に AST が上昇しており， APAP による心筋 障害を発現した可能性が考えられる。APAPによ る心毒性の報告は，自殺目的で 1 回に APAP $4.8 \mathrm{~g}$ を服用した症例23) と $15 \mathrm{~g}$ を服用した症例24)があ る。しかし，いずれも大量投与による報告であり， 通常の臨床用量において APAPによる心毒性を発 現した報告はなされていない。高用量 APAP 投与 については，ほかにもいくつかの報告で安全性につ いて検討が行われている。変形性関節症患者を対象 として APAP 1 回 $1000 \mathrm{mg}, 1$ 日 $4000 \mathrm{mg}$ を 6 週間 投与し副作用に関する検討を行った 2 文献 25,26$)$ にお いては, 消化器症状の発現頻度が多かったものの, いずれも軽度のものと判断されている．また，同様 に変形性関節症患者を対象として APAP 1 日 3900 $\mathrm{mg}$ 又はナプロキセン 1 日 $1000 \mathrm{mg}$ を連続 8 週間投

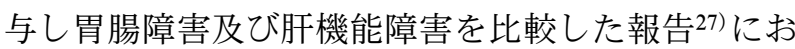
いて，2 群間でいずれも有意差はなかったとしてい る. さらに, がん疼痛患者 45 例を対象として, APAP 1 日 2000-4000 mg 4 週間投与した報告 ${ }^{28)}$ では, 肝 機能検査值及び腎機能検査值に有意な変化はなく, 安全に使用できたとしている。しかし，Kurtovic
ら 299 は重い栄養不良患者に APAP 1 日 $4000 \mathrm{mg}$ を 投与したところ重篤な肝機能障害を引き起こしたと 報告している。 また，Prescottらは APAP の肝毒 性に影響を及ぼす因子として，栄養不良，アルコー ル摂取，人種及び年齢等を挙げている。等) 血清中 APAP 濃度と副作用の関係は APAP 単回投与にお いて相関性があり, Clark ら ${ }^{31}$ は APAP 単回大量 投与（24-75 g/回）による肝障害やそれによる死亡 例を報告している。血清中 APAP 濃度が投与 4 時 間後で $300 \mathrm{mg} / 1$ 以上， 12 時間後で $45 \mathrm{mg} / 1$ 以上の 場合に重篤な肝毒性発現の可能性があり，投与 4 時 間後で $120 \mathrm{mg} / 1$ 以下， 12 時間後で $30 \mathrm{mg} / 1$ 以下で あれば肝毒性発現の可能性は低いとされている. ${ }^{32)}$ 今回の結果において，投与直前の血清中 APAP 濃 度（投与後 6 時間值）は 3.1-15.8 mg/1 であった。 APAP の消失半減期は約 3 時間18) であることから 消失速度定数は約 $0.231 \mathrm{~h}^{-1}$ となる。 また，APAP 坐剂及び内服剂の最高血清中濃度到達時間は約 1-2 時間18,19) であることから，APAP 投与後 4 時間以降 は，消失相であると考えられる，よって，本結果に おける投与後 6 時間值から推定した投与後 4 時間及 び 12 時間の血清中 APAP 濃度は，4.9-25.1 mg/1 及び 0.8-4.0 mg/1 と計算される。したがって，肝 毒性を引き起こす可能性が高いと報告されている濃 度よりもはるかに低い值であり，単回投与の場合で あれば安全な濃度域であると考えられた。

以上より，院内特殊製剤として調製した高用量 APAP 坐剂は, 臨床使用可能であると考えられ, 経口摂取不能ながん疼痛患者に対して有用な製剂で あると考えられた。しかし，栄養障害を有している 患者，心不全患者あるいは高齢者では APAP の副 作用が懸念されることから，十分に副作用をモニ夕 リングしながら慎重に使用する必要があると考えら れた。また，高用量 APAP の長期投与に関する十 分な安全性の臨床報告はなく, 今後, 症例を積み重 ね検討していかなければならない課題である.

3. オキシコドン注射剤の適正使用に関する検討 わが国において，2003 年 7 月にオキシコドン徐 放錠（オキシコンチン®錠）が上市され，現在，が ん疼痛患者に対してその使用頻度が増加傾向にあ る。オキシコドン徐放錠は WHO 方式がん疼痛治 療法の第 3 段階に位置する経口強オピオイド鎮痛薬 であり，経口モルヒネ徐放製剤の代替薬として有用 
性が高い。その理由として，経口オキシコドンと経 ロモルヒネの鎮痛効果及び副作用について臨床的な 相違が認められない33-36)ことや，オキシコドンとそ の活性代謝物のオキシモルフォンは肝臓でほとんど 代謝されるため腎機能障害患者においても高度な血 清中濃度上昇はなく，比較的安全に使用可能である こと等が挙げられる. ${ }^{37)}$ 一方，モルヒネは腎機能障 害患者に使用した場合，活性代謝物の排泄が極度に 遅延し, ${ }^{38,39)}$ 副作用が増強することが報告されてい る. 40-44)一方，末期がん患者においては，認知障害 や嚥下困難のため持続的な経口薬治療が不可能にな ることがあり，その場合経口以外の投与経路を選択 する. ${ }^{45)}$ オキシコドン徐放錠で鎮痛コントロールさ れていた患者で経口摂取不能となった場合，わが国 ではオキシコドンの坐剤あるいは経皮吸収型製剤は 上市されていないため，注射剂を使用する必要があ る。しかし，わが国にはオキシコドン単独成分の注 射剤は存在せず，オキシコドンとヒドロコタルニン の合剤（複方オキシコドン注射剤；パビナール®注） が上市されているのみである。複方オキシコドン注 射剤に含まれるヒドロコタルニンは，オキシコドン の鎮痛効果を増強する目的で配合されているが，そ の根拠となるデータ46-48) は乏しく，血清中薬物動態 の報告はない，また，オキシコドン単独成分の注射 剂においてもがん疼痛患者を対象とした血清中薬物 動態の検討は海外で報告された 1 報49)のみであり， がん疼痛患者における複方オキシコドン注射剤の薬 物動態学的デー夕は不十分である。また，複方才キ シコドン注射剤の血清中薬物濃度変動因子を確認し た報告はなく，複方オキシコドン注射剂をがん疼痛 患者に適正に臨床使用するためには，個々の患者に 合わせた投与量設計を行う必要があると考えられ た。さらに，複方オキシコドン注射剤の添付文書上 の適応は「激しい疼痛時における鎮痛」であり，が 儿疼痛患者へ臨床使用した報告はない。そのため, がん疼痛患者へ複方オキシコドン注射剂を安全に臨 床使用可能であるかは不明であり，オキシコドン徐 放錠から複方オキシコドン注射剂への用量変換比も 確立されていない。そこで，がん疼痛患者に対する 複方オキシコドン注射剤の適正使用を目的に，オキ シコドン及びヒドロコタルニンの同時血清中濃度測 定方法を確立し，がん疼痛患者におけるオキシコド ン及びヒドロコタルニンの血清中動態及びクリアラ
ンス変動因子について検討を行った。ささらに，オキ シコドン徐放錠と複方オキシコドン注射剂を使用し たがん疼痛患者に対して薬剤変更前後での鎮痛効果 及び副作用を調査し，用量変換比について検討を行 った。

3-1. 複方オキシコドン注射剤の血清中薬物動態 の検討 50) 対象患者は，複方オキシコドン注射剤 による鎮痛コントロールが行われたがん疼痛患者 19 名とした。投与方法は，持続静注，持続皮下注 あるいは点滴静注とした。オキシコドン及びヒドロ コタルニン血清中濃度測定法は，HPLC-ECD ${ }^{51)} に$ て行い，採血は，持続静注及び持続皮下注の場合， 投与開始後 $4,8,12,24$ 時間及び 48 時間以降の計 5 ポイント, 点滴静注の場合（点滴時間； 60-80 分 間)，点滴終了直後，点滴開始 2 時間後及び 6 時間 後の計 3 ポイントを原則として行った。薬物動態 は，非線形最小二乗法プログラム (MULTI) ${ }^{52,53)}$ を 用い，1-コンパートメントモデルで解析した。ま た，算出したオキシコドン及びヒドロコタルニンの クリアランスに対する影響因子を検討するために, 重回帰分析（ステップワイズ法）を行った。予測因 子として，年齢，性別，体重，平均血圧，AST，

$\mathrm{ALT}$ ，血清クレアチニン，クレアチニンクリアラ ンス，及び 7 日以内の死亡，肝転移あるいは心不全 の有無をモデルに組み込んだ。

その結果，持続静注又は持続皮下注の患者は 17 例，点滴静注の患者は 2 例であり，得られた血清中 薬物濃度の総数は 42 ポイントであった。算出され た薬物動態パラメータは，オキシコドン；Vd（分 布容積 $)=226.7 \pm 105.51$ (Mean \pm S.D. ) , CL（ク リアランス) $=37.9 \pm 25.1 \mathrm{l} / \mathrm{h}, \quad \mathrm{t}_{1 / 2}=4.1 \pm 1.9 \mathrm{~h}$, ヒ ドロコタルニン ; $\mathrm{Vd}=276.8 \pm 237.21, \mathrm{CL}=95.1 \pm$ $64.3 \mathrm{l} / \mathrm{h}, \mathrm{t}_{1 / 2}=2.0 \pm 0.7 \mathrm{~h}$ であった.

また，オキコドン及びヒドロコタルニンのクリア ランスに対する影響因子を検討した結果，オキコド ンクリアランスに関しては，年齢及び 7 日以内の死 亡，肝転移あるいは心不全の有無との間に重回帰式 で表される有意差がみられた（Oxycodone clearance $=-1.459 \times$ age $-18.876 \times($ within 7 days on the death, liver metastasis or heart failure) $+134.994, \mathrm{R}^{2}$ $=0.517, p=0.001)$. また，ヒドロコタルニンクリ アランスに関しては，7 日以内の死亡，肝転移ある いは心不全の有無との間に重回帰式で表される有意 
差がみられた（Hydrocotarnine clearance $=73.402 \times$ (within 7 days on the death, liver metastasis or heart failure) + 116.395, $\left.\mathrm{R}^{2}=0.287, p=0.027\right)$.

さらに，7 日以内の死亡, 肝転移あるいは心不全 患者群及び死亡前 8 日以上, 肝転移なしあるいは心 不全なし患者群に分け，Mann-Whitney’s $U$ 検定を 行ったところ，オキシコドンクリアランス及びヒド ロコタルニンクリアランスは，それぞれ $p=0.035$ 及び $p=0.044$ と有意な差が認められ， 7 日以内の 死亡，肝転移あるいは心不全患者群の方が両薬物の クリアランスは低值であった（Fig. 1，オキシコド

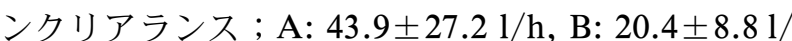
$\mathrm{h}$, ヒドロコタルニンクリアランス ; A: $119.4 \pm$ 64.4 l/h, B: $50.6 \pm 35.1$ l/h)。また，オキシコドン クリアランスを体重で除した值と年齢との間に負の 相関関係が認められた（Fig. 2, r=0.654）。

オキシコドン薬物動態パラメータは，CL；37.91/ $\mathrm{h}, \mathrm{Vd} ; 226.71$ と算出され，海外でのがん疼痛患者 における報告値（CL; 48.61/h, Vd;211.91) ${ }^{49}$ と比 較して, クリアランスは低值，分布容積はほぼ同等 の值を示していた．海外の報告と比較しクリアラン スが低值を示した理由として，母集団の相違が考え られる．今回の対象患者は，終末期患者（7日以内 に死亡)，肝転移患者及び心不全患者等の状態の悪 い症例が含まれていたため, クリアランスが低值で あったと推察された。 ヒドロコタルニン薬物動態パ ラメータは，CL; 95.11/h, Vd; 276.81 と算出さ れ，オキシコドンに比ベ分布容積及びクリアランス は高值であった。 日本人がん疼痛患者におけるオキ シコドン及びヒドロコタルニン薬物動態パラメータ
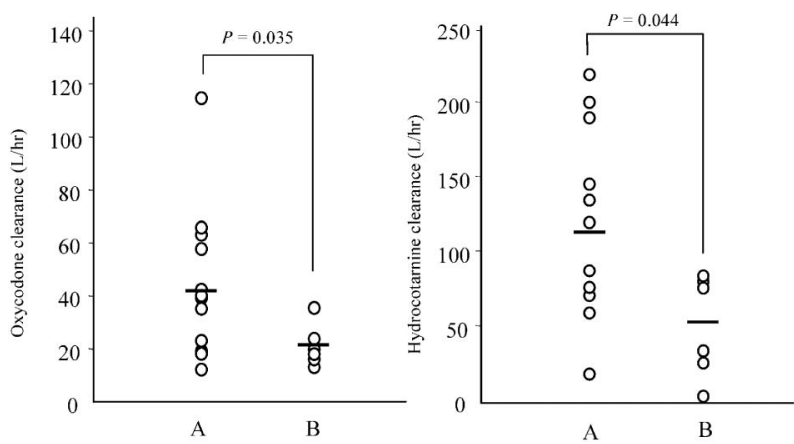

Fig. 1 Influence Factors in Oxycodone and Hydrocotarnine Clearance

A, No cardiac failure, no liver metastasis, or 8 days or more before death and B, Cardiac failure, liver metastasis, or within 7 days on the death.
の報告はなく，本研究により初めて明らかとなった.

オキシコドン及びヒドロコタルニンクリアランス に対する影響因子を検討したところ，オキシコドン のクリアランスは，年齢及び終末期患者（7 日以内 に死亡)，肝転移あるいは心不全の有無が有意な変 動因子として挙げられた。 また，年齢とオキシコド ンクリアランスの相関関係の検討では，高齢になる に従いオキシコドンクリアランスは低值を示した. オキシコドンは肝臓で約 $80 \%$ 代謝されることか ら, オキシコドンクリアランスの変動要因は肝機能 の影響が大きいと考えられ，肝転移の有無がオキシ コドンクリアランスの有意な変動因子になったと考 えられた，Tallgren ら54の報告では，肝移植患者に おいて，移植前と移植後でオキシコドンを静注した 場合，消失半減期は平均 13.9 時間から 3.4 時間に 短縮したとしている。 また，Weinstein ら55は，才 キシコドン徐放錠において, 肝機能障害患者では健 常成人に比べ，AUC は約 2 倍，最高血清中濃度は 約 1.5 倍上昇したと報告している。これらの報告か らも，オキシコドンは肝機能の状態により血清中濃 度が大きく変動することが考えられた.

また，オキシコドンの全身クリアランスは健常成 人では $46.8 \mathrm{l} / \mathrm{h}(=780 \mathrm{ml} / \mathrm{min}),{ }^{56)}$ がん疼痛患者で は $48.6 \mathrm{l} / \mathrm{h} \quad(=810 \mathrm{ml} / \mathrm{min}),{ }^{57)}$ 本結果では $37.9 \mathrm{l} / \mathrm{h}$ (=632 $\mathrm{ml} / \mathrm{min})$ と算出されている。一般的な成人 の肝血流速度は約 $800 \mathrm{ml} / \mathrm{min}$ であり，オキシコド ンはほとんど肝臓で代謝されることから全身クリア

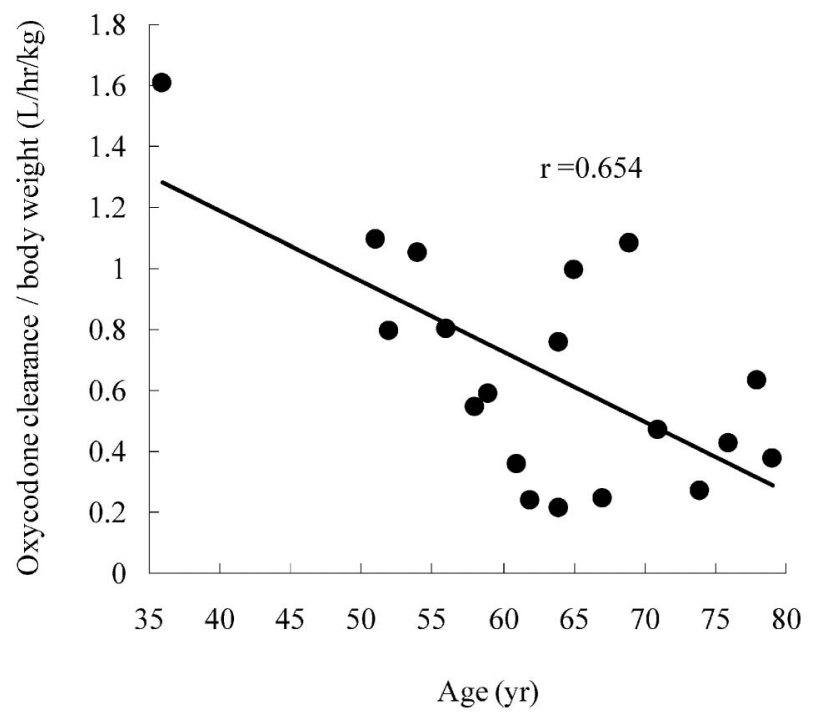

Fig. 2 Relationship between Oxycodone Clearance and Age 
ランスは肝クリアランスとみなすことができるた め, オキシコドンクリアランスは肝血流速度の変化 に大きく影響を受けることが考えられる．このこと から，終末期患者（7 日以内に死亡）及び心不全患 者では，循環血流量の低下が考えられ，肝血流速度 低下がオキシコドンクリアランス低下の大きな要因 の1つと考えられた。 また，ヒドロコタルニンに関 しても，オキシコドンと同じ予測因子によりヒドロ コタルニンクリアランスの変動因子を検討した。そ の結果，終末期患者（7 日以内に死亡），肝転移あ るいは心不全の有無が有意な変動因子として挙げら れた。しかし，ヒドロコタルニンは排泄部位が不明 であることから，これら変動因子が有意となつた理 由は不明である。

以上より，高齢者，終末期患者（7 日以内に死 亡)，肝転移患者，心不全患者においては，複方才 キシコドン注射剤の血清中薬物濃度が上昇する可能 性が考えられ，このような患者に複方オキシコドン 注射剂を使用する場合は，投与量を減量する等の注 意が必要であると考えられた。

\section{3-2. オキシコドン徐放錠と複方オキシコドン注} 射剂における用量変換比の検討 ${ }^{58)}$ 対象患者は,

オキシコドン徐放錠から複方オキシコドン注射剤, 又は複方オキシコドン注射剤からオキシコドン徐放 錠へ変更を行った患者 18 名とした.

オキシコドン徐放錠と複方オキシコドン注射剤の 用量変換比は, 疼痛の程度が同等となった投与量比 を用量変換比とし, 薬剂変更前後での鎮静度の変 化，呼吸抑制，嘔気及び排便の変化について調査を 行った。疼痛の評価については, NRS（numeric rating scale）を用い, ${ }^{59,60)}$ 鎮静度の評価については RSS (ramsay sedation score) ${ }^{61)}$ を用いた。ささらに, 呼吸抑制，嘔気及び排便の変化については，薬剤変 更後, 患者自身が評価し薬剤師による患者聞き取り 調査を行った。

その結果, 疼痛の程度が同等となつた用量変換比 （注射剂の投与量/徐放錠の投与量）は，平均 0.71 \pm 0.12 (Mean \pm S.D.）であった。また，変更前後 における疼痛強度（NRS）及び副作用（RSS，呼吸 抑制，嘔気，便秘）に変化はなかつた.

今回の結果は，オキシコドン徐放錠から複方オキ シコドン注射剤への変更において同等の鎮痛効果を 示す用量変換比は $0.73 \pm 0.09$ (Mean \pm S.D.） であ
つたとする丸山らの結果62) と一致していた。しか し，丸山らの報告は 9 例で検討しており，われわれ の検討は 18 例と幅広い母集団であった。がん疼痛 患者を対象に PCA（patient-controlled analgesia） ポンプを用いてオキシコドン単独成分の注射剤を投 与した海外での臨床研究では，オキシコドン内服剤 との用量変換比は，0.70であったと報告してい

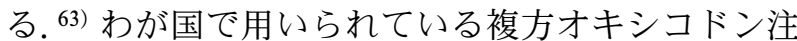
射剂は鎮痛効果を増強させる目的でヒドロコタルニ ンを配合しているため，これまで，オキシコドン徐 放錠から複方オキシコドン注射剂へ変更を行う場合 にはその作用も考慮しなければならないと考えられ てきた。しかし，本結果はオキシコドン単独成分の 注射剂を用いて行われた海外での臨床研究63) とほぼ 同等な用量変換比であり，オキシコドン徐放錠のバ イオアベイラビリティ（60-87\%）ともほぼ一致し ていた. ${ }^{64,65)}$ また, 変更前後の副作用についても検 討した結果，鎮静度，呼吸抑制，嘔気及び排便とも に変化はなく，算出された用量変換比で安全に臨床 使用可能であることが示された。

以上，今回の検討によりヒドロコタルニンによる オキシコドンの鎮痛作用増強は非常に少ないと考え られ，複方オキシコドン注射剤とオキシコドン徐放 錠の用量変換比は約 0.7 であると考えられた.

\section{4. オキシコドン徐放錠の適正使用に関する検討}

オキシコドン徐放錠（オキシコドン®錠）の吸収 動態は，オキシコドン徐放錠とオキシコドン水溶液 を同時に行った母集団薬物動態解析において，投与

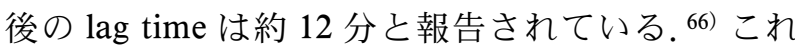
により，オキシコドン徐放錠は効果発現が早いと発 売当初より報告され，頓服使用している施設が存在 する。しかし，オキシコドン徐放錠は，モルヒネ徐 放錠（MS コンチン錠）の薬物放出機構の欠点で ある短い鎮痛効果持続時間を改善した製剤であ り, ${ }^{67)}$ その徐放システムは，徐放性マトリックスに よりオキシコドンの放出を制御していることから即 効性があるとは考え難い。 ${ }^{68)}$ したがって，オキシコ ドン徐放錠の頓服使用は不適切と考えられ，事実， われわれはオキシコドン徐放錠使用後，効果発現ま で 1 時間程度必要であった症例を経験している.

また，オキシコドン徐放錠を服用した患者におい て，錠剤が糞便中にそのままの形状で排出された症 例が各施設で多数報告され，その中に薬物が残存し 
ていれば追加投与の必要性が懸念された。オキシコ ドン徐放錠は，アミノアルキルメタクリレートコポ リマーRS とステアリルアルコールの 2 重膜によっ てオキシコドンの放出を制御しており，オキシコド ンが放出された後はアミノアルキルメタクリレート コポリマーRS で被覆された顆粒の微小穴となる が，これはある程度の強度を有するため，錠剤形状 は崩壊しないことが in vitro 溶出試験で確認されて いる. ${ }^{69,70)}$ しかし，実際の患者の粪便中に排出され たオキシコドン徐放錠（ghost pill）にオキシコド ンがどの程度含有されているかは明らかにされてい ない.

そこで，オキシコドン徐放錠の不適切な頓服使用 を是正し，さらに糞便中から ghost pill が排出され た際の追加投与の必要性を検討することにより，才 キシコドン徐放錠の適正使用法を確立することを目 的として，オキシコドン徐放錠の吸収動態及び ghost pill 中のオキシコドン残存量について検討を 行った.

4-1. オキシコドン徐放錠の吸収動態の検討71) 対象患者は，オキシコドン徐放錠で鎮痛コント ロールが行われたがん疼痛患者 7 名とした．投与方 法は，1 日 2 回 12 時間毎の繰り返し投与とし，食 事の 1 時間前の投与とした。血清中オキシコドン濃

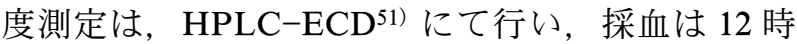
間毎にオキシコドン徐放錠を 4 回以上投与した定常 状態における投与後 $0,1,2,3,6$ （又は 8） 及び 12 時間後の計 6 ポイントを原則として行った。吸収動 態は，非線形最小二乗法プログラム (MULTI) ${ }^{52,53)}$ で解析した。

その結果, 薬物動態パラメー夕は, $\mathrm{Vd} / \mathrm{F} ; 473.0$ \pm 196.71 (Mean \pm S.D.), kal; $1.082 \pm 0.604 \mathrm{~h}^{-1}$, lag time; $0.99 \pm 0.40$ 時間であった。 lag time は，約 1 時間と算出され，血清中オキシコドン濃度は投与後 1 時間以降に急激に上昇した（Fig. 3).

Sunshine ら ${ }^{72)}$ の報告では，血清中オキシコドン 濃度は測定されていないが，オキシコドン徐放錠内 服後効果発現まで $10 \mathrm{mg}$ 投与群で 61.5 分間, 20 $\mathrm{mg}$ 投与群で 58 分間, $30 \mathrm{mg}$ 投与群で 46 分間を要 したとしており，われわれの結果を支持するものと 考えられた。しかし，Mandema ら ${ }^{66)}$ の報告では， わが国の製剤と同一徐放機構を有するオキシコドン 徐放錠とオキシコドン水溶液の同時母集団薬物動態

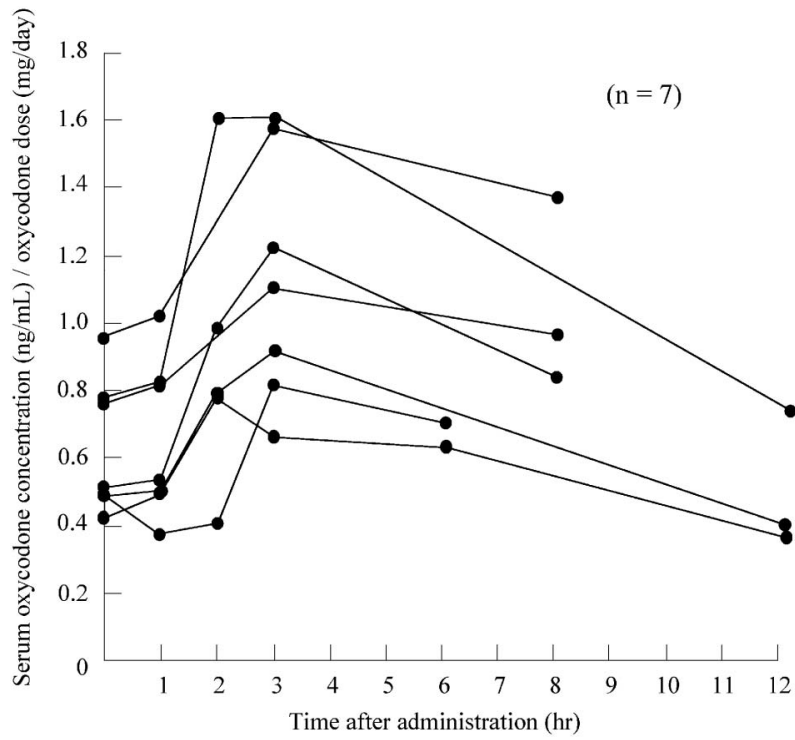

Fig. 3 Serum Concentrations of Oxycodone in Cancer Pain Patients Following Administrations of Controlled-release Oral Oxycodone at Steady State

解析において，2 相性の吸収を示し初期の吸収は比 較的速やかであるとしており, lag time は約 12 分 と算出している．また，オキシコドン徐放錠の溶出 試験69)において，試験開始後 30 分までに 21.5-33.1 \%のオキシコドンが溶出している.これらのことか ら，オキシコドン徐放錠は，投与初期に比較的速や かに一部のオキシコドンを放出するが，効果発現に は，一定の時間を要すると考えられ，頓服使用可能 であるとは考え難い．また，今回のわれわれの検討 では空腹時投与で設定しているが，健常成人で解析 した報告ではオキシコドン徐放錠は食後投与に比べ 空腹時投与の方が吸収が速いと報告されている. ${ }^{73)}$ このことから，食後投与の場合， lag time は 1 時間 以上になることが予想された，以上，オキシコドン 徐放錠の lag time は約 1 時間と算出され，がん疼 痛患者における突出痛（急激な一過性の疼痛）に対 し，頓服使用は不適切であると考えられた。

4-2. 粪便中から排出された ghost pill 中のオキ シコドン残存量の検討74) 対象患者は，粪便中か ら ghost pill が排出された北里大学病院と国立がん センター中央病院の 2 症例とし, ghost pill 中の才 キシコドン残存量測定方法は，まず，糞便中から排 出された ghost pill は，前処理として，錠剤に付着 している便を拭き取った後，乳鉢ですりつぶし，蒸 留水 $20 \mathrm{ml}$ で抽出し，メンブランフィルターでろ過 
後，ろ液を測定用試料とした。オキシコドン含量測 定は，HPLC-ECD ${ }^{51)} に て$ 行った.

症例 1 及び 2 で発見された ghost pill 中のオキシ コドン残存量を測定した結果，それぞれ $0.0034 \mathrm{mg}$ (20 mg 錠)， $0.0037 \mathrm{mg}(20 \mathrm{mg}$ 錠）と微量であっ た.

以上より, ghost pill 中のオキシコドン残存量は 微量であり，オキシコドンは消化管内で十分に放出 されていると考えられた。したがって，ghost pill が糞便中から排出されたとしてもオキシコドン徐放 錠を追加投与する必要はないと考えられた。

5. フェンタニルパッチの適正使用に関する検 討75,76)

フェンタニルパッチ（デュロテップ®パッチ，リ ザーバータイプ）は，支持体，薬物貯蔵層，放出制 御膜, 粘着層及びライナー（台紙）の 5 層構造から なる製剤である，貼付後，主成分であるフェンタニ ルは放出制御膜により一定速度で放出され，表皮か ら受動拡散により吸収されて, 肝初回通過効果を受 けずに直接体循環に移行する。 $2.5 \mathrm{mg}, 5.0 \mathrm{mg}, 7.5$ $\mathrm{mg}$ 及び $10.0 \mathrm{mg}$ 製剤におけるフェンタニルの放出 速度は，それぞれ $25 \mu \mathrm{g} / \mathrm{h}, 50 \mu \mathrm{g} / \mathrm{h}, 75 \mu \mathrm{g} / \mathrm{h}$ 及び $100 \mu \mathrm{g} / \mathrm{h}$ であり，フェンタニルパッチからのフェ ンタニル放出量は各製剤の貼付面積に比例する. ${ }^{77)}$ フェンタニルパッチは，経皮吸収製剤であるため使 用法が簡便であり，燕下困難な患者に対しても使用 可能なことから，患者の QOL 改善や医療従事者及 び介護者の負担軽減が期待できる薬剤である，わが 国では，モルヒネからの切り替えによってのみ使用 可能であり，換算表に基いて貼付用量が決定され る. ${ }^{77)}$

フェンタニルパッチは 72 時間毎の貼り替えで安 定した鎮痛効果が維持できるとされているが，海外 では 48 時間毎の貼付例78)や皮膚加温による放出促 進79) も報告されている。.すなわち，貼付後 72 時間 血清中フェンタニル濃度が維持できない例が存在す ることが推測され，その場合には十分な鎮痛効果が 得られないことが懸念される。事実，われわれは貼 付後 3 日目に疼痛が出現する症例や投与量を増量し ても鎮痛が得られない症例を経験している。そのた め，フェンタニルパッチの臨床使用においては，患 者における血清中薬物動態を十分に把握しておくこ とが重要である，日本人がん疼痛患者を対象とした
フェンタニルパッチの血清中薬物動態に関する報告 は，水口ら ${ }^{80,81)}$ による報告のみであるが，症例数も 少なく不十分であり薬物動態を詳細に把握できる データではない。一方，フェンタニルパッチ（リ ザーバータイプ)の最小規格は $2.5 \mathrm{mg}$ 製剤であり, フェンタニルパッチ $2.5 \mathrm{mg}$ 製剤を初回投与した際 やフェンタニルパッチ $2.5 \mathrm{mg}$ 製剂から $5.0 \mathrm{mg}$ 製剤 へ増量した際に，呼吸抑制を起こした患者を数例経 験している。フンンタニルパッチは製剤学的に半量 にすることができないため，臨床においてはより低 用量のフェンタニルパッチ製剤が望まれている。そ こで，がん疼痛患者においてフェンタニルパッチを 適正に臨床使用することを目的として，フェンタニ ルパッチ貼付後の血清中フェンタニル濃度推移及び 低用量を投与する方法として半面貼付法について検 討を行った。

対象患者は，フェンタニルパッチによる鎮痛コン トロールが行われたがん疼痛患者 44 名とした。フ エンタニルパッチの投与量は，換算表に従い，前投 薬されたモルヒネ 1 日使用量を基に決定し， 72 時 間毎の貼り替えとした。採血は，フェンタニルパッ 于貼付 2 回目以降の貼付後 24 時間，48 時間あるい は 72 時間を原則とし, 沼田らの方法 ${ }^{82}$ に従い LC/ MS/MS により血清中フェンタニル濃度を測定し た。半面貼付方法は，まずフェンタニルパッチ 2.5 $\mathrm{mg}$ 製剂の用量印刷面にフェンタニルパッチを 2 等 分する線を記入した，次に創傷保護等に用いる医療 用ドレッシングテープのテガダーム ${ }^{\circledR}$ (スリーエム ヘルスケア K.K.）を皮膚に貼付した後，フェンタ ニルパッチの半分はテガダームの上に，半分は皮膚 に直接付くように貼付した。

フェンタニルパッチ投与量と血清中フェンタニル 濃度との相関分析を行った結果，相関係数は，貼付 後 19-30 時間值で $r=0.9567$, 貼付後 45-55 時間値 で $r=0.8785$, 貼付後 65-79 時間值で $r=0.9351$ （Fig. 4）であり，フェンタニルパッチ投与量が 25$1000 \mu \mathrm{g} / \mathrm{h}$ の範囲内で血清中フェンタニル濃度は, 用量比例性を示した。このことから，血清中フェン タニル濃度の変動はあるものの，投与量が 25-1000 $\mu \mathrm{g} / \mathrm{h}$ の範囲内では投与量の増加に伴い血清中フェ ンタニル濃度も上昇することが明らかとなった。

また，一貼付期間内に 2 ポイント以上採血を行っ た症例を抽出し，個体内におけるフェンタニルパッ 


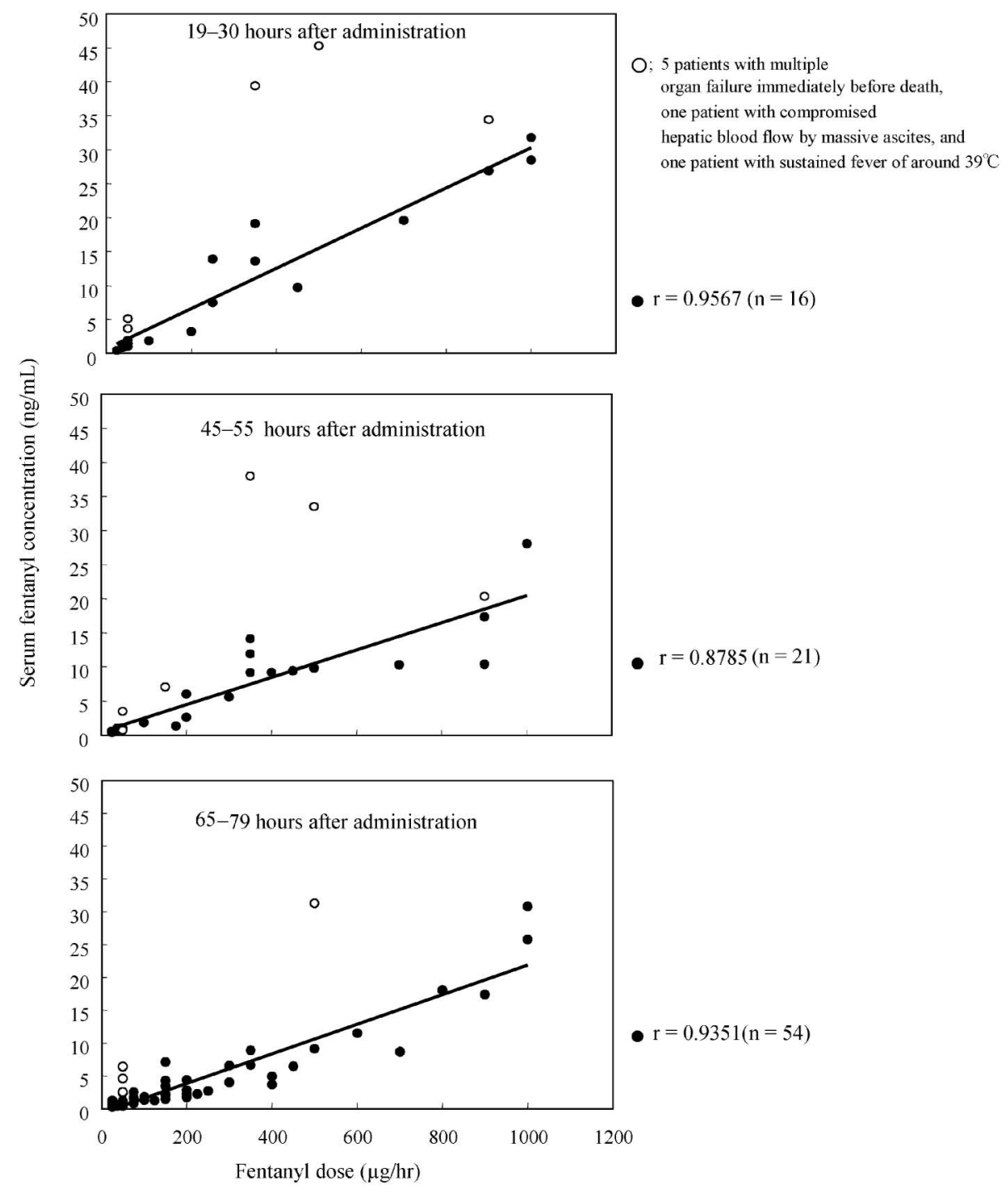

Fig. 4 Relationships between Serum Fentanyl Concentrations and Transdermal Fentanyl Doses Patient serum samples were collected after the second application of transdermal fentanyl was over.

チ一貼付期間内の血清中フェンタニル濃度変動につ いて対応のある分散分析を行った。 その結果，2448 時間, $24-72$ 時間及び 48-72 時間の $p$ 值は, そ れぞれ $0.0038,<0.0001$ 及び 0.0029 と有意差を示 し, 貼付後 24 時間から 72 時間にかけて血清中フェ ンタニル濃度は経時的に低下した。 また, 貼付後 19-25 時間, 貼付後 45-52 時間及び貼付後 65-72 時 間の血清中濃度を投与量で除した值の平均值は，そ れぞれ $0.030 \pm 0.013(\mathrm{ng} / \mathrm{ml} / \mu \mathrm{g} / \mathrm{h}), 0.023 \pm 0.007$ $(\mathrm{ng} / \mathrm{ml} / \mu \mathrm{g} / \mathrm{h})$ 及び $0.014 \pm 0.003(\mathrm{ng} / \mathrm{ml} / \mu \mathrm{g} / \mathrm{h})$ で あり, 貼付後 65-72 時間值は, 貼付後 19-25 時間値 の約 47\%にまで低下していた（Fig. 5).

このことから, 貼付 3 日目では血清中フェンタニ ル濃度低下に伴い鎮痛効果が減弱し, 疼痛が出現す
る可能性が考えられた. Robertson ら ${ }^{83)}$ は, ネコに おいてフェンタニルを静脈内投与し血清中フェンタ ニル濃度と鎮痛効果（熱刺激に対する閾值の変動） を測定したところ, 血清中フェンタニル濃度低下に 伴い鎮痛効果は減弱したと報告している，このこと から，ヒトにおいても同様なことが予想され，事 実, われわれはフェンタニルパッチを使用した患者 で貼付後 3 日目に疼痛が出現する症例を多数経験し ている. また, 健常成人を対象として, モルヒネ点 滴静注後の血清中モルヒネ濃度と鎮痛効果を検討し た報告84)では，血清中モルヒネ濃度低下に伴い鎮痛 効果も減弱することを示している。 また，Payne ら の報告 ${ }^{85)}$ では，フェンタニルパッチを使用した患者 の $23.5 \%$ が 72 時間毎の貼り替えでは，十分な鎮痛 


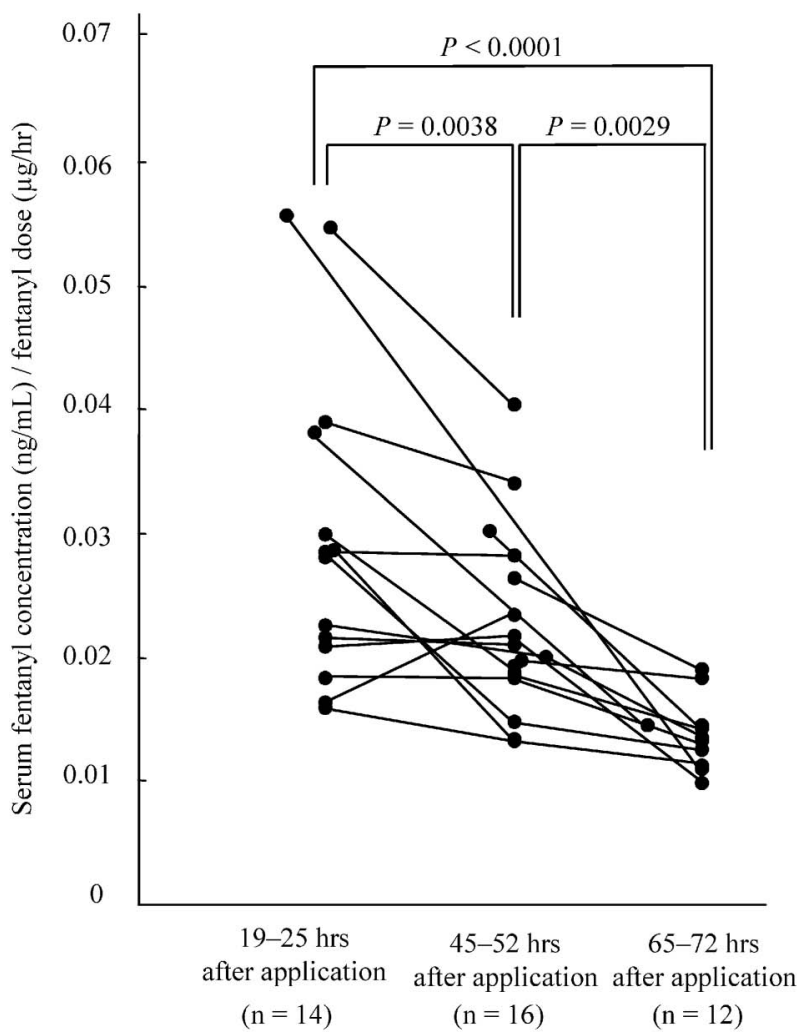

Fig. 5 Intraindividual Variability of Serum Fentanyl Concentration in the Samples Collected at Two or More Time-points within Each Patch Application

コントロールができなかつたとしており，米国の添 付文書では 72 時間毎で鎮痛コントロールが不十分 な場合は，48 時間毎の貼り替えを考慮する旨の記 載がなされている．以上，フェンタニルパッチは投 与量が $25-1000 \mu \mathrm{g} / \mathrm{h}$ の範囲内で, 投与量の増加に 比例して血清中フェンタニル濃度が上昇することを 確認した。また，フェンタニルパッチは 3 日間，同 等の血清中フェンタニル濃度が維持されないことが 明らかとなり，貼付後 3 日目では鎮痛効果が減弱す る可能性が考えられた。わが国における用法は，72 時間毎に貼付することとなっているが，貼付後 3 日 目に疼痛が出現した場合には，血清中フェンタニル 濃度が低下した可能性が考えられ，48 時間毎の貼 り替えを考慮に入れる必要があると考えられた。

さらに, $2.5 \mathrm{mg}$ 製剤半面貼付時及び $2.5 \mathrm{mg}$ 製剂 貼付時における貼付後 48-72 時間の血清中フェンタ ニル濃度は，それぞれ $0.286 \pm 0.200 \mathrm{ng} / \mathrm{ml}$ （Mean \pm S.D.）及び $0.544 \pm 0.265 \mathrm{ng} / \mathrm{ml}$ であり，有意な 差が得られた $(p=0.011) .2 .5 \mathrm{mg}$ 製剤半面貼付時 の平均血清中フェンタニル濃度は $2.5 \mathrm{mg}$ 製剤貼付
時の約 53\%にまで低下していた. Mercadante ら ${ }^{86}$ は, $2.5 \mathrm{mg}$ 製剤から 2 倍量の $5.0 \mathrm{mg}$ 製剤に増量し た 2 症例で，精神症状，起立性低血圧，嘔気等を発 現した症例を報告し，増量時に細かい用量設定が可 能となる $1.25 \mathrm{mg}$ 製剤が必要であると論じている. また，Peng らの報告87)では，われわれと同様の半 面貼付の試みを行っており，血清中フェンタニル濃 度は測定しないものの，その有用性を論じている. さらに，Otis ら ${ }^{88)}$ の報告では，フェンタニルパッ チ $1.25 \mathrm{mg}$ 製剤の臨床的有用性と安全性を検討して おり， $1.25 \mathrm{mg}$ 製剂を開始量としたほうが $2.5 \mathrm{mg}$ 製剂で開始した今までの報告と比較して副作用発現 に起因する脱落が少なく，患者からの評価も良好で あったと報告している.

\section{6. 硫酸モルヒネ徐放細粒の適正使用に関する検} 討 89 )

頭頸部がん等の患者では，腫瘍部位や病状進行に よって経口摂取不能となり経鼻カテーテル（以下， カテーテル）により栄養剤や薬剤を投与することが ある。このような患者に対し，強オピオイド鎮痛薬 の治療を行う場合，2001 年 9 月に上市された硫酸 モルヒネ徐放細粒（モルペス細粒）の有用性は高 い。硫酸モルヒネ徐放細粒は平均粒子径が 0.25 $\mathrm{mm}$ と微細であり，経鼻管投与が可能であるが，力 テーテル等への付着やカテーテル閉塞を引き起こす ことが考えられた。硫酸モルヒネ徐放細粒の経鼻管 投与時の適正使用法に関する報告はなく，医療用麻 薬の管理の面からも早急に検討する必要があった. そこで今回，様々な分散液及びカテーテルを用い, 模擬的経鼻管投与実験を行うことにより，その適正 使用方法について検討を行った.

\section{6-1. 外観観察におけるシリンジ内の付着実験} 硫酸モルヒネ徐放細粒プラセボ $0.5 \mathrm{~g}$ をカップに 採取し, 各種分散液をカップの目盛りで $20 \mathrm{ml}$ まで 加え, シリンジで吸引後，排出した。 さらに，用い た分散液 $10 \mathrm{ml}$ で洗浄し最後に蒸留水 $10 \mathrm{ml}$ で洗浄 した。実験は 3 回繰り返し，2名のスタッフにより シリンジ内の付着性を目視で観察した。また，事前 にシリンジ内を蒸留水で洗浄した場合と洗浄しなか った場合に分け，分散液を蒸留水として上記の操作 を行い付着の程度を比較した。

その結果を Table 3 に示した。 ヤクルト®，のむ ヨーグルト，カルピスキッズ®，森永クリープ®液, 
Table 3. The Adhesion of Morphes ${ }^{\circledR}$ Fine Granules in the Syringe under Various Dispersion Liquid

\begin{tabular}{|c|c|c|c|}
\hline \multirow{2}{*}{ Dispersion liquid } & \multicolumn{3}{|c|}{ Number of times } \\
\hline & 1 & 2 & 3 \\
\hline Distillated water & $4+$ & $4+$ & $4+$ \\
\hline $\begin{array}{l}\text { Distillated water } \\
\text { (pre-washed the inside of syringe) }\end{array}$ & $1+$ & $1+$ & $1+$ \\
\hline Little warm water $\left(37^{\circ} \mathrm{C}\right)$ & $3+$ & $3+$ & $3+$ \\
\hline YAKULT $^{\circledR}$ & - & \pm & \pm \\
\hline $100 \%$ Orange juice (Minute Maid $^{\mathbb{}}$ ) & $1+$ & $1+$ & $1+$ \\
\hline Nomu yogurt (plain) & - & - & - \\
\hline CALPIS kids ${ }^{\circledR}$ & - & - & - \\
\hline Creap ${ }^{\circledR}$ & - & - & - \\
\hline Creamy & - & - & - \\
\hline Milk & \pm & \pm & - \\
\hline Saline $\left(\right.$ Physisalz $\left.^{\mathbb{Q}}\right)$ & $5+$ & $5+$ & $5+$ \\
\hline $5 \%$ glucose injection & $3+$ & $3+$ & $3+$ \\
\hline $20 \%$ glucose injection & $2+$ & $2+$ & $2+$ \\
\hline $50 \%$ glucose injection & $1+$ & $1+$ & $1+$ \\
\hline Ensure $^{\circledR} \mathrm{H}$ & - & - & - \\
\hline $\operatorname{Racol}^{\circledast}$ & - & \pm & \pm \\
\hline Twinline $^{\circledR}$ & $3+$ & $3+$ & $3+$ \\
\hline Clinimeal $^{\circledR}$ & - & - & - \\
\hline Elental $^{\circledR}$ & $1+$ & $1+$ & $1+$ \\
\hline Intralipos ${ }^{\circledR} 20 \%$ & $3+$ & $3+$ & $3+$ \\
\hline KATSUODASHI soup $\left(2 \mathrm{~g} / 100 \mathrm{ml}, 30^{\circ} \mathrm{C}\right)$ & $1+$ & $1+$ & $1+$ \\
\hline Creamy $5 \mathrm{ml}+$ Distillated water $15 \mathrm{ml}$ & $1+$ & $1+$ & $1+$ \\
\hline
\end{tabular}

Key クリーミー液，牛乳，エンシュア ${ }^{\circledR} \mathrm{H} ，$ ラコー ル®，クリニミールを分散液とした場合，硫酸モル ヒネ徐放細粒プラセボの付着は $(-)-( \pm)$ とほと んど認められなかったが, 蒸留水, 生理食塩液, 5

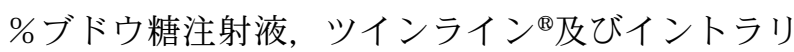
ポス ${ }^{\circledR} 20 \%$ を分散液とした場合，（3＋）以上であり 付着は多かった。 また，分散液を蒸留水として，事 前にシリンジ内を蒸留水で洗浄した場合と洗浄しな かつた場合を比較したところ，洗浄することにより シリンジ内の付着の程度は $(4+)$ から $(1+)$ へ大 幅に減少した。さらに, ブドウ糖注射液は高濃度ほ ど付着が減少する傾向にあった。

6-2. カップ, シリンジ及びカテーテル内のモル ヒネ残存率及びカテーテルへの注入時間の検討 硫酸モルヒネ徐放細粒 $0.5 \mathrm{~g}$ 又は $5.0 \mathrm{~g}$ をカップ に採取し, 外観観察実験で良好な結果を得た分散液 及び対照として蒸留水を用い，それぞれの分散液を カップの目盛りで $20 \mathrm{ml}$ まで加え, シリンジで吸引
後, 各種カテーテルに注入した. さらに, 同様の分 散液 $10 \mathrm{ml}$ でカテーテルを洗浄し, 最後に蒸留水 $10 \mathrm{ml}$ で洗浄した. また, 同時にカテーテルへの注 入時間も測定した. 上記操作により模擬的経鼻管投 与実験を行った後, カップ, シリンジ及びカテーテ ル内の残存モルヒネ量を HPLCにて測定した.

その結果, 蒸留水ではシリンジ内に投与量の約 $65 \%$ のルヒネが残存していた。また，牛乳，エン シュア ${ }^{\circledR} \mathrm{H}$, ヤクルト『゙は, カップ, シリンジ及び カテーテルの残存モルヒネはほとんど認められなか

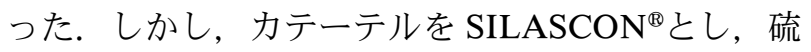
酸モルヒネ徐放細粒 $5.0 \mathrm{~g}$ を注入した場合カテーテ ル内が閉塞してしまった。 また, 硫酸モルヒネ徐放 細粒 $0.5 \mathrm{~g}$ 及び $5.0 \mathrm{~g}$ の注入時間は, 牛乳では NIPRO；19.7 秒及び 36.3 秒, SILASCON ${ }^{\circledR} ; 10.3$ 秒及び「注入不能」, $\operatorname{argyle}^{\circledR} ; 8.7$ 秒及び 21.5 秒, エンシュア ${ }^{\circledR} \mathrm{H}$ では NIPRO；29.7 秒及び 40.3 秒, SILASCON $^{\circledR ｝ ; 29.3 \text { 秒及び「注入不能」, } \operatorname{argyle}{ }^{\circledR} \text {; }$ 15.7 秒及び 44.7 秒，ヤクルト®では NIPRO；9.0 秒及び 20.0 秒，SILASCON ${ }^{\circledR} ; 11.0$ 秒及び「注入 不能」, $\operatorname{argyle}{ }^{\circledR} ; 7.0$ 秒及び 20.0 秒であった。分散 液として牛乳及びヤクルトを用いた場合はエンシ

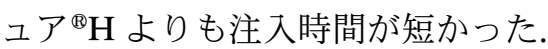

以上より, 乳製品及びカゼイン含有の経腸栄養剤 は, 硫酸モルヒネ徐放細粒における経鼻管投与時の 分散液として使用可能であることが考えられた。一 方, 分散液を蒸留水, 生理食塩液, $5 \%$ ブドウ糖注 射液，カゼイン非含有の経腸栄養剤であるツインラ インあるいは脂肪乳剂であるイントラリポス ${ }^{\circledR} 20 \%$ にした場合, 付着は多く硫酸モルヒネ徐放細粒の分 散液として使用不可であると考えられた。ささらに， 硫酸モルヒネ徐放細粒を大量投与する際は, カテー

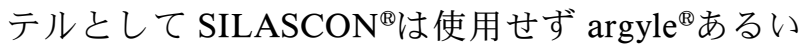
はNIPRO を使用すべきであると考えられた.

\section{まとめ}

以上, 本研究により, WHO 方式がん疼痛治療法 で推奨されている様々な種類のがん疼痛治療薬を適 正に臨床使用することが可能となった。まず， WHO 方式がん疼痛治療法の第 1 段階である高用量 アセトアミノフェン坐剤が, 1 回 1 個で臨床使用可 能になつた。第 3 段階である複方オキシコドン注射 剂では, 高齢, 心不全, 肝転移及び終末期の患者に おいて，血清中薬物濃度が上昇するため減量投与す 
るべきであることを解明した，また，複方オキシコ ドン注射剤とオキシコドン徐放錠との用量変換比は 0.7 であることを明らかとし，適正な用量変換が可 能になった。オキシコドン徐放錠では，頓服使用は 不適切であることを明らかとした。また, ghost pill が糞便中から排出されたとしてもオキシコドン 徐放錠の追加投与は不要であることを見い出した. フェンタニルパッチを使用している患者において は，貼付後 3 日目に疼痛が出現した場合，血清中フ エンタニル濃度低下が考えられ 2 日毎の貼付方法も 鎮痛コントロールとして有用であると考えられた。 また，硫酸モルヒネ徐放細粒を経鼻管投与する際の 適正な分散液を明らかとし，適正な経鼻管投与法を 確立した。本研究では，これらのがん疼痛治療薬の 臨床使用上の問題点を解決したことで，WHO 方式 がん疼痛治療法を第 1 段階から第 3 段階にわたり， がん疼痛治療薬の適正な臨床使用を可能とした。本 研究の成果は，わが国におけるがん疼痛治療を推進 するための重要な知見を整備したと考えられた.

謝辞稿を終えるにあたり本研究に際し, 終始 御鞭撻，御指導を賜りました東京薬科大学天然医薬 品化学教室竹谷孝一教授に深謝いたします。また, 臨床研究に際して御指導を賜りました東京薬科大学 薬物動態制御学教室林 正弘教授，東京薬科大学製 剂設計学教室岡田弘晃教授, 東京薬科大学臨床薬剂 学研究室太田 伸教授に深謝いたします。また，本 研究の遂行にあたり，一方ならぬ御配慮と御督励を 頂きました北里大学医学部麻酔科, 北里大学病院薬 剂部及び東京薬科大学臨床薬効解析学教室の皆様に 深甚なる謝意を表します。

\section{REFERENCES}

1) Twycross R. G., Fairfield S., Pain, 14, 303310 (1982).

2) Bonica J. J., "The Management of Pain, Cancer pain: Current status and future needs," 2nd ed., Lea \& Febiger, Philadelphia, 1990, pp. 400-445.

3) Kane R. L., Wales J., Bernstain L., Leibowitz A., Kaplan S., Lancet, 21, 890-894 (1984) .

4) Foley K. M., N. Engl. J. Med., 313, 84-95 (1985)

5) Tsuneto S., Ikenaga M., Hosoya J., The
Japanese Journal of Hospice and Palliative Care, 6, 482-490 (1996).

6) World Health Organization, "Cancer Pain Relief," WHO, Geneva, 1986.

7) Stjernswärd J., Colleau S. M., Ventafridda V., J. Pain Symptom Manage., 12, 65-72 (1996)

8) Jadad A. R., Browman G. P., JAMA., 274, 1870-1873 (1995).

9) Grond S., Zech D., Schug S. A., Lynch J., Lehmann K. A., J. Pain Symptom Manage., 6, 411-422 (1991).

10) Hanks G., "Oxford Textbook of Palliative Medicine," eds. by Doyle D., Hanks G., Cherny N., Calman K., 2nd ed., Oxford University Press, Oxford, p. 342, 1999.

11) Amrican Pain Society, "Guideline for the Management of Cancer Pain in Adults and Children,"' pp. 53-54, 2005.

12) Kokubun H., Toshi K., Matoba M., Hoka S., Yago K., Pallative Care Research, 1, 311-316 (2006)

13) Yomiya K., Nippon Rinsho, 65, 49-54 (2007).

14) Matoba M., Clinical Gastroenterology, 22 , 173-178 (2007).

15) Suzuki T., Journal of Pain and Clinical Medicine, 6, 136-139 (2006).

16) Moore A., Collins S., Carroll D., McQuay H., Edwards J., Cochrane Database Syst. Rev., CD001547 (2000).

17) Shinoda S., Aoyama T., Aoyama Y., Tomioka S., Matsumoto Y., Ohe Y., Biol. Pharm. Bull., 30, 157-61 (2007).

18) Anhiba ${ }^{\circledR}$ Interview Form

19) Malan J., Moncrieff J., Bosch E., Br. J. Clin. Pharmacol., 19, 843-845 (1985).

20) Rawlins M. D., Henderson D. B., Hijab A. R., Eur. J. Clin. Pharmacol., 11, 283-286 (1977).

21) Walter-Sack I., Luckow V., Guserle R., Weber E., Arzneim.-Forsch., 39, 719-724 (1989).

22) Van der Marel C. D., Van Lingen R. A. Pluim M. A., Scoones G., van Dijk M., Vaandrager J. M., Tibboel D., Clin. Pharmacol. Ther., 70, 82-90 (2001).

23) Nishikawa Y., Fujii Y., Miyauti Y., Maekawa T., Aoki H., Sakabe T., Japanese Journal of Intensive Care Medicine, 11, 483-488 (1987). 24) Price L. M., Poklis A., Johnson D. E., J. 
Forensic. Sci., 36, 930-935 (1991).

25) Williams H. J., Ward J. R., Egger M. J., Neuner R., Brooks R. H., Clegg D. O., Field E. H., Skosey J. L., Alarcón G. S., Willkens R. F., Paulus H. E., Russell I. J., Sharp J. T., Arthritis. Rheum., 36, 1196-1206 (1993).

26) Pincus T., Koch G. G., Sokka T., Lefkowith J., Wolfe F., Jordan J. M. Luta G., Callahan L. F., Wang X., Schwartz T., Abramson S. B., Caldwell J. R., Harrell R. A., Kremer J. M., Lautzenheiser R. L., Markenson J. A., Schnitzer T. J., Weaver A., Cummins P., Wilson A., Morant S., Fort J., Arthritis. Rheum., 44, 1587-1598 (2001).

27) Do J.-H., Hur S.-E., Paek S.-I., Nah J.-M., Kim C.-H., Lee S.-H., Park S.-H., Cho C.-S., Kim H.-Y., Kim W.-U., J. Korean Rheum. Assoc., 11, 14-24 (2004).

28) Matoba M., Yoshimoto T., Yomiya K., Tomiyasu S., Tamaki T., Hashizume T., Kokubun H., Ryu E., Pain Clinic, 28, 1131-1139 (2007).

29) Kurtovic J., Riordan S. M., J. Intern. Med., 253, 240-243 (2003).

30) Prescott L. F., Am. J. Ther., 7, 99-114 (2000)

31) Clark R., Borirakchanyavat V., Davidson A. R., Thompson R. P., Widdop B., Goulding R., Williams R., Lancet, 13, 66-69 (1973).

32) Anderson P. O., Knoben J. E., Troutman W. G., "Handbook of Clinical Drug Data," 10th ed., McGraw-Hill, New York, 2001, p. 16.

33) Bruera E., Belzile M., Pituskin E., Fainsinger R., Darke A., Harsanyi Z., Babul N., Ford I., J. Clin. Oncol., 16, 3222-3229 (1998) .

34) Heiskanen T., Kalso E., Pain., 73, 37-45 (1997).

35) Mucci-LoRusso P., Berman B. S., Silberstein P. T., Citron M. L., Bressler L., Weinstein S. M., Kaiko R. F., Buckley B. J., Reder R. F., Eur. J. Pain, 2, 239-249 (1998).

36) Reid C. M., Martin R. M., Sterne J. A., Davies A. N., Hanks G. W., Arch. Intern. Med., 166, 837-843 (2006).

37) Heiskanen T., Olkkola K. T., Kalso E., Clin. Pharmacol. Ther., 64, 603-611 (1998).

38) Osborne R., Joel S., Grebenik K., Trew D., Slevin M., Clin. Pharmacol. Ther., 54, 158167 (1993).

39) Pauli-Magnus C., Hofmann U., Mikus G.,
Kuhlmann U., Mettang T., Nephrol. Dial. Transplant., 14, 903-909 (1999)

40) Mercadante S., Palliat. Med., 13, 95-104 (1999)

41) Bruera E., Brenneis C., Paterson A. H., J. Pain Symptom Manage., 4, 3-6 (1989).

42) Covington E. C., Gonsalves-Ebrahim L., Currie K. O., Shepard K. V., Pippenger C. E., Psychosomatics, 30, 226-228 (1989).

43) Angst M. S., Bührer M., Lötsch J., Anesthesiology, 92, 1473-1476 (2000).

44) Sjøgren P., Dragsted L., Christensen C. B., Acta Anaesthesiol. Scand., 37, 780-782 (1993).

45) Mercadante S., Cancer, 86, 1856-1866 (1999).

46) Okushima K., Okayama Igakkai Zasshi, 425, 612-623 (1925).

47) Uetsuka K., Kushima K., Nippon Yakurigaku Zasshi, 42, 137-147 (1947).

48) "The Japanese Pharmacopoeia, 14th edition,', C-856-859, 2001.

49) Leow K. P., Smith M. T., Williams B., Cramond T., Clin. Pharmacol. Ther., 52, 487-495 (1992).

50) Kokubun H., Fukawa M., Matoba M., Hoka S., Yamada Y., Yago K., Biol. Pharm. Bull., 30, 2173-2177 (2007).

51) Kokubun H., Ouki M., Matoba M., Kubo H., Hoka S., Yago K., Anal. Sci., 21, 337-339 (2005)

52) Yamaoka K., Tanigawara Y., Nakagawa T., Uno T., J. Pharmacobiodyn., 4, 879-885 (1981).

53) Yamaoka K., Nakagawa T., J. Pharmacobiodyn., 6, 595-606 (1983).

54) Tallgren M., Olkkola K. T., Seppälä T., Höckerstedt K., Lindgren L., Clin. Phamacol. Ther., 61, 655-661 (1997).

55) Weinstein S. H., Gaylord J. C., J. Pharm. Sci., 68, 527-528 (1979).

56) Poyhia R., Olkkola K. T., Seppala T., Kalso E., Br. J. Clin. Pharmacol., 32, 516-518 (1991).

57) Smith M. T., Watt J. A., Mapp G. P., Cramond T., Ther. Drug Monit., 13, 126-130 (1991).

58) Kokubun H., Nakamura K., Fukawa M., Matoba M., Hoka S., Yago K., Japanese Journal of Cancer and Chemotherapy, 34, 
2255-2258 (2007).

59) De Conno F., Caraceni A., Gamba A., Mariani L., Abbattista A., Brunelli C., La Mura A., Ventafridda V., Pain, 57, 161-166 (1994).

60) Paice J. A., Cohen F. L., Cancer Nurs., 20, 88 -93 (1997).

61) Ramsay M. A., Savege T. M., Simpson B. R., Goodwin R., Br. Med. J., 2, 656-659 (1974).

62) Maruyama M., Matoba M., Ito N., Isono M., Murakami S., Kokubun H., Ito T., Hoka S., Japanese Journal of Palliative Medicine, 17, 65-69 (2005)

63) Kalso E., Vainio A., Clin. Pharmacol. Ther., 47, 639-646 (1990).

64) Reder R. F., Oshlack B., Miotto J. B., Benziger D. D., Kaiko R. F., Clin. Ther., 18, 95105 (1996).

65) Leow K. P., Smith M. T., Williams B., Cramond T., Clin. Phamacol. Ther., 52, 487-495 (1992).

66) Mandema J. W., Kaiko R. F., Oshlack B., Reder R. F., Stanski D. R., Br. J. Clin. Pharmacol., 42, 747-756 (1996).

67) Kaiko R. F., Takeda F., Symptom Management in Cancer Patients, 16, 57-64 (2005).

68) Ozaki M., Medicine and Drug Journal, 40, 302-309 (2004).

69) Shionogi \& Co., Ltd., OxyContin tablets product information, 2001.

70) Anderson D. T., Fritz K. L., Muto J. J., J. Anal. Toxicol., 26, 448-459 (2002).

71) Nakamura K., Kokubun H., Komatsu T., Matoba M., Hoka S., Yago K., Japanese Journal of Cancer and Chemotherapy, 34, 1449-1453 (2007).

72) Sunshine A., Olson N. Z., Colon A., Rivera J., Kaiko R. F., Fitzmartin R. D., Reder R. F., Goldenheim P. D., J. Clin. Pharmacol., 36, 595-603 (1996).

73) Benziger D. P., Kaiko R. F., Miotto J. B., Fitzmartin R. D., Reder R. F., Chasin M., $J$. Pharm. Sci., 85, 407-410 (1996).

74) Kokubun H., Murakami S., Matoba M., Ito
T., Shima Y., Hoka S., Yago K., Journal of Japanese Society of Hospital Pharmacists, 40, 1011-1013 (2004).

75) Kokubun H., Matoba M., Hoka S., Yamada Y., Yago K., Jpn. J. Pharm. Health Care Sci., 33, 200-205 (2007).

76) Kokubun H., Matoba M., Okazaki M., Hoka S., Yago K., Yakugaku Zasshi, 128, 447-450 (2008).

77) Durotep ${ }^{\circledR}$ MT Patch Interview Form.

78) Ashburn M. A., Ogden L. L., Zhang J., Love G., Basta S. V., J. Pain, 4, 291-297 (2003).

79) Donner B., Zenz M., Strumpf M., Raber M., J. Pain Symptom Manage., 15, 168-175 (1998).

80) Mizuguchi K., Yamamura H., Takeda F., Hiraga Y., Abe R., Toda T., Ariyoshi H., Tsuneto S., Ohashi Y., Medicine and Drug Journal, 37, 2403-2426 (2001).

81) Mizuguchi K., Yamamura H., Takeda F., Hiraga Y., Abe R., Tsuneto S., Medicine and Drug Journal, 37, 2389-2402 (2001).

82) Numata C., Teraoka R., Matsuda Y., Mitani A., Miyanaga Y., Yagi K., Hirai M., Jpn. J. Pharm. Health Care Sci., 31, 599-605 (2005).

83) Robertson S. A., Taylor P. M., Sear J. W., Keuhnel G., J. Vet. Pharmacol. Ther., 28, 8793 (2005).

84) Dahan A., Romberg R., Teppema L., Sarton E., Bijl H., Olofsen E., Anesthesiology, 101, 1201-1209 (2004).

85) Payne R., Chandler S., Einhaus M., Anticancer Drugs, 6, 50-53 (1995).

86) Mercadante S., Villari P., Ferrera P., J. Pain Symptom Manage., 21, 448-449 (2001).

87) Peng Y. R., Sun W. Z., Mok M. S., J. Pain Symptom Manage., 30, 7-8 (2005).

88) Otis J., Rothman M., Curr. Med. Res. Opin., 22, 1493-1501 (2006).

89) Kokubun H., Ito T., Murase S., Shimada S., Journal of New Remedies and Clinics, 52, 461 -469 (2003). 